\title{
Incidence and Causes of Postharvest Fruit Rot in Stored Michigan Cranberries
}

\author{
R. O. Olatinwo and A. M. C. Schilder, Department of Plant Pathology, and A. N. Kravchenko, Department of Crop \\ and Soil Sciences, Michigan State University, East Lansing 48824
}

\begin{abstract}
Olatinwo, R. O., Schilder, A. M. C., and Kravchenko, A. N. 2004. Incidence and causes of postharvest fruit rot in stored Michigan cranberries. Plant Dis. 88:1277-1282.

The incidence of postharvest fruit rot and associated fungi was studied in stored cranberries in Michigan in 2000 and 2001. Ripe cranberries were harvested from eight commercial farms in southwest and northeast Michigan, including the Upper Peninsula. Eight cranberry cultivars were represented: Stevens, Searles, Le Munyon, Pilgrim, Ben Lear, Bergman, Beckwith, and WSU 61. Fruit rot incidence was assessed within 1 week after harvest. Remaining sound fruit was stored for 2 months at $5^{\circ} \mathrm{C}$, and fungi were isolated from rotted fruit after 1 and 2 months of storage. Year and region, but not cultivar, significantly affected the overall rate of rot development in storage. Storage rot levels generally were lower in 2001 than in 2000, particularly in southern Michigan. A high incidence of field rot at harvest did not necessarily lead to a high incidence of storage rot. Storage rot tended to be more severe in the northern than in the southern growing region. Fungi most frequently associated with storage rot were Fusicoccum putrefaciens, Colletotrichum acutatum, Coleophoma empetri, Phomopsis vaccinii, and Phyllosticta elongata. F. putrefaciens was the predominant storage rot fungus in northern Michigan in both years and caused up to $80 \%$ fruit rot in storage. C. empetri and P. elongata also were isolated more frequently from beds in northern than southern Michigan in 2001. The cvs. Pilgrim and Stevens were more susceptible to storage rot caused by Colletotrichum acutatum, and Bergman and WSU 61 were more susceptible to storage rot caused by Phomopsis vaccinii than some of the other cultivars.
\end{abstract}

Additional keywords: berry speckle, black rot, blotch rot, end rot, Godronia cassandrae, Physalospora vaccinii, ripe rot, Vaccinium macrocarpon, viscid rot, yellow rot

Michigan has a long history of cranberry (Vaccinium macrocarpon Aiton) production. Early records show over a dozen commercial cranberry operations in the state at the beginning of the twentieth century (3). Most of these operations eventually disappeared for reasons that are not entirely clear. The demand for cranberries during the last decade has stimulated renewed interest and, today, there are about 100 ha of commercial cranberry beds in the state. Except for a farm in the Upper

Corresponding author: A. M. C. Schilder

E-mail: schilder@msu.edu

The study was supported in part by the Michigan Cranberry Council, the GREEEN Project (Generating Research and Extension to meet Economic and Environmental Needs) at Michigan State University, and the Michigan Agricultural Experiment Station.

American Type Culture Collection (ATCC) accession numbers: Allantophomopsis lycopodina (MYA-1154), Botrytis cinerea (MYA-1158), Coleophoma empetri (MYA-1162), Colletotrichum acutatum (MYA-1159), Fusicoccum putrefaciens (MYA-1155), Pestalotia vaccinii (MYA-1161), Phomopsis vaccinii (MYA-1156), and Physalospora vaccinii (MYA-1157).

Accepted for publication 2 July 2004.

Publication no. D-2004-0907-02R

(C) 2004 The American Phytopathological Society
Peninsula that has produced cranberries for over a century, most plantings are less than 9 years old and situated in the Lower Peninsula of Michigan.

Harvested cranberry fruit is used in one of two ways: (i) processed into juice, sauce, and a variety of other products; or (ii) marketed directly as fresh fruit. Fruit harvested for the fresh market generally is cleaned and placed in refrigerated storage for several weeks to months until the holiday periods in November and December (8). Fresh fruit accounts for about $10 \%$ of total North American crop sales (9). Across the cranberry-producing states, fruit rots are a major concern because they affect quality of both fresh-market and processed fruit and can lead to serious losses (8). Fruit rot in storage can result from fungal infection, physiological breakdown, or both $(4,8)$.

It is well established that cranberry fruit rot is a complex disease caused by over 15 different fungal species $(1,2,8,12,14)$. There is considerable overlap between field and storage rot organisms. For example, Physalospora vaccinii (Shear) Arx \& E. Müller can cause fruit rot in the field as well as in storage. On the other hand, Phyllosticta vaccinii Earle is predominantly a field rot pathogen, whereas Allantophomopsis spp. typically are storage rot pathogens $(2,8)$. Storage rot pathogens infect berries during either the growing season or the harvesting process $(5,15,17)$. Wet harvests and wounding of fruit generally increase the risk of infection by storage rot fungi $(11,17)$.

Field rot, caused by a variety of fungal pathogens, is common in Michigan cranberry beds (7). Black rot, caused by Allantophomopsis spp., was observed in several samples of healthy-looking berries harvested from Michigan cranberry beds in 1999 and stored at $5^{\circ} \mathrm{C}$ for 5 months (7). This led us to believe that storage rot might be more common than previously assumed; however, no studies had been done to assess the importance of storage rot in cranberries in Michigan. This study was conducted to determine the incidence of and pathogens associated with storage rot, and builds on a previous study of field rot in Michigan cranberries (7). Both studies are part of a larger project aimed at assessing yield constraints and improving disease and pest management practices in commercial cranberry production in Michigan.

\section{MATERIALS AND METHODS}

Sample collection and evaluation. In 2000 and 2001, fruit from 33 and 28 cranberry beds, respectively, were collected on eight commercial farms in Michigan, including the Upper Peninsula (UP). These were the same samples and locations described in a study of field rot by Olatinwo et al. (7). In 2001, fewer beds were sampled because some beds were taken out of production for economic reasons. Eight cranberry cultivars were sampled: Stevens, Searles, Le Munyon, Pilgrim, Ben Lear, Bergman, Beckwith, and WSU 61. With a few exceptions, there was one bed per cultivar per farm. Samples were taken in 2000 and 2001 from the following locations: Whitefish Point (UP) (four beds of Stevens and four beds of Searles), Cheboygan (three beds of Stevens, one bed of Pilgrim, and one bed of Le Munyon), North Blendon (two beds of Stevens in 2000, one bed of Stevens in 2001), Pullman (one bed of Stevens in 2000, none in 2001), South Haven A (one bed each of Beckwith, Stevens, Pilgrim, Bergman, Ben Lear, and WSU 61), South Haven B (one bed each of Stevens and Pilgrim), Covert (one bed each of Stevens, Pilgrim, and WSU 61), and Lawton (two beds of Stevens and one bed of Pilgrim in 2000; none in 2001). Just prior to harvest (late September to early October), 100 berries were selected arbitrarily along a diagonal transect through each bed. Incidence of fruit rot symptoms was visually determined and 
recorded within 1 week after harvest. Incidence of field rot and associated fungi was reported in Olatinwo et al. (7). The remaining nonsymptomatic berries in each sample were stored in plastic bags in a cold room at $5^{\circ} \mathrm{C}$ and re-examined after 1 and 2 months of storage. At each time, cranberries showing rot symptoms were removed and enumerated. All symptomatic berries were surface disinfested in $1.5 \% \mathrm{NaOCl}$ for $90 \mathrm{~s}$ and cut in half transversely. One half of each berry (the flower end) was placed with the cut surface down on nonclarified V8-juice agar (160 $\mathrm{ml}$ of V8 juice, $3 \mathrm{~g}$ of $\mathrm{CaCO}_{3}, 15 \mathrm{~g}$ of agar, and $840 \mathrm{ml}$ of deionized $\mathrm{H}_{2} \mathrm{O}$ ). Plates were incubated at room temperature $\left(20\right.$ to $\left.25^{\circ} \mathrm{C}\right)$ and ambient light for 3 to 4 weeks. Fungi were identified directly on the agar plates by comparing morphological characteristics of the spores and spore-producing structures with descriptions in the literature $(2,14)$.

Statistical analysis. Using PROC GLM in SAS (version 8; SAS Institute, Cary, $\mathrm{NC}$ ), the incidence of fruit rot was regressed linearly against the storage duration ( 0,1 , and 2 months), where 0 months represents the harvest period. Rot percentages at harvest were attributed to field rot and were the same as listed in Olatinwo et al. (7). The resulting slopes, which represent the rate of increase of rot during storage, were analyzed using SAS PROC MIXED to determine effects of year, region, and cultivar (within region) on the incidence of storage rot. Mixed model analysis was chosen because the study included a mixture of random and fixed effects. Farms were grouped into two climatically distinct regions in order to assess differences between the growing regions and to assess cultivar effects, because many cultivars were not replicated within farms but were replicated within regions. The farms located in Whitefish Point (UP) and Cheboygan (northern Lower Peninsula) were assigned to the northern region and the remaining farms were assigned to the southern region. The effects of year, region, and cultivar (within region) were evaluated similarly on the rates of increase of individual species of fungi in stored fruit after log transformation of the (non-zero) slopes. Leastsquares means (LS means) of fixed effects were used for mean separation at the 95\% confidence level.

Differences in the frequency of occurrence of the various fungi between the regions were assessed by $\chi^{2}$ analysis of $2 \times$ 2 contingency tables using $\chi^{2}$ and Fisher's exact tests (PROC FREQ in SAS). Contingency tables were prepared by counting the total number of beds in each region (13 beds in the north and 20 beds in the south in 2000, and 13 beds in the north and 15 beds in the south in 2001) and determining the number of those beds in which a specific fungus was detected in fruit stored for 2 months at $5^{\circ} \mathrm{C}$.
For each cranberry bed, the cumulative incidence of individual fungi in fruit was regressed linearly on the cumulative rot percentage after 1 and 2 months of storage using StatGraphics Plus 4.1 (Manugistics, Inc., Rockville, MD) to assess which fungi were most closely associated with an occurrence of storage rot. A correlation was considered significant if $P \leq 0.10$ and $R^{2} \geq 0.95$. The less conservative threshold $P$ value of 0.10 was chosen to allow for nonlinear relationships between the variables. Correlations were deemed to be of biological significance if $\beta$ (the slope) was between 1 and 10. Higher slopes would suggest that less than $10 \%$ of the total rot percentage would be related to a specific fungus.

\section{RESULTS}

The incidence of storage rot in Michigan cranberries varied widely among farms in both 2000 and 2001 (Figs. 1A and 2A). Storage rot is indicated by a significant rise in cumulative rot incidence after 1 or 2 months of storage at $5^{\circ} \mathrm{C}$. In general, storage rot levels were higher in 2000 than in 2001, and also higher in the northern than in the southern region. In some cases, a moderate to high percentage of cranberries showed field rot symptoms at harvest (e.g., in Lawton). The amount of field rot did not appear to be related to increased rot development in storage, as evidenced by the relatively flat slopes on several farms, particularly in the southern region (Figs. $1 \mathrm{~A}$ and $2 \mathrm{~A}$ ).

Mixed model analysis showed that year and region, but not cultivar (within region), significantly affected the rate of increase (slope) of rot in storage (Table 1). There also was a significant region $\times$ year interaction effect on the rate of storage rot development. Although there were significant differences among cultivars in field rot incidence at harvest (7), the slopes of the lines did not differ significantly among cultivars (Figs. 1A and 2A).

A variety of fungi were isolated from cranberries showing rot symptoms after 1 and 2 months of storage, and fungal profiles differed by location and year (Figs. $1 \mathrm{~B}$ and 2B). Fusicoccum putrefaciens Shear (teleomorph: Godronia cassandrae Peck) (end rot) and Coleophoma empetri (Rostr.) Petr. (ripe rot) were present at particularly high levels in some fruit samples, but Colletotrichum acutatum J. H. Simmonds (bitter rot), Phomopsis vaccinii Shear in Shear, N. Stevens, \& H. Bain, (viscid rot), and Phyllosticta elongata G. J. Weidemann in G. J. Weidemann, D. M. Boone, \& Burdsall (Botryosphaeria fruit rot and berry speckle) also were commonly isolated from fruit that developed rot during storage. Allantophomopsis lycopodina (Hohn) Carris (black rot), Physalospora vaccinii (blotch rot), Botrytis cinerea Pers.:Fr. (yellow rot), Pestalotia vaccinii (Shear) Guba, and Alternaria spp. were isolated more sporadically. Species in the latter two genera generally are considered to be weak pathogens or saprophytes $(2,8)$.

Analysis of the $2 \times 2$ presence-by-region contingency tables with Fisher's exact tests showed that $F$. putrefaciens occurred in significantly more cranberry beds in the north than in the south in both years $(P<$ 0.0001; Table 2). Coleophoma empetri and Phyllosticta elongata also were found in more beds in the north than in the south in $2001(P=0.0018$ and 0.0016 , respectively; Table 2). Statistically, the other fungi occurred no more frequently in one region than the other in either year. However, in 2000, Colletotrichum acutatum and Coleophoma empetri tended to be more common in the south and Phomopsis vaccinii tended to be more common in the north (Table 2).

The incidence of $F$. putrefaciens in stored fruit was correlated significantly with cumulative storage rot incidence at 0 , 1 , and 2 months in the majority of cranberry beds in the north but not the south in both years (Table 3 ). Additional fungi that were correlated significantly with storage rot incidence in either the north or the south were C. empetri, Colletotrichum acutatum, Phyllosticta elongata, and Phomopsis vaccinii (Table 3). No significant correlations were found for any other fungi or, if they were significant, their incidence was so low compared with total fruit rot levels that they were considered unimportant.

Mixed model analysis showed that the rates of increase of specific fungi during storage were significantly affected by year (Coleophoma empetri, $P=0.0099$; Colletotrichum acutatum, $P<0.0001$; Phomopsis vaccinii, $P<0.0001$; and Phyllosticta elongata, $P=0.0064)$; region ( $F$. putrefaciens, $P=0.0156)$; region $\times$ year $(C . e m-$ petri, $P<0.0001$, and $P$. elongata, $P=$ $0.0035)$; cultivar (region) ( $F$. putrefaciens, $P=0.0315 ; C$. acutatum, $P<0.0001$; and Phomopsis vaccinii, $P=0.0506)$; and year $\times$ cultivar (region) (C. acutatum, $P<$ 0.0001 , and $P$. vaccinii, $P<0.0001$ ). The rates of increase of the latter two fungi then were analyzed separately by region to better understand the year $\times$ cultivar interactions. In the south, year, cultivar, and year $\times$ cultivar significantly affected the rate of increase of $C$. acutatum during storage $(P=0.0021, P=0.0021$, and $P<$ 0.0001 , respectively). According to the LS means method, Pilgrim and Stevens fruit yielded significantly more $C$. acutatum after storage than Bergman, Beckwith, and WSU 61 in $2000(P<0.05)$. There were no significant differences in 2001. The increase of $P$. vaccinii in stored fruit from southern Michigan also was significantly affected by year $(P=0.0032)$, cultivar $(P<$ $0.0001)$, and year $\times$ cultivar $(P<0.0001)$. In 2000, for example, Bergman was more susceptible to $P$. vaccinii storage rot than Stevens, Pilgrim, Ben Lear, and Beckwith. In addition, WSU 61 was more susceptible than Pilgrim and Ben Lear $(P<0.05)$. In 

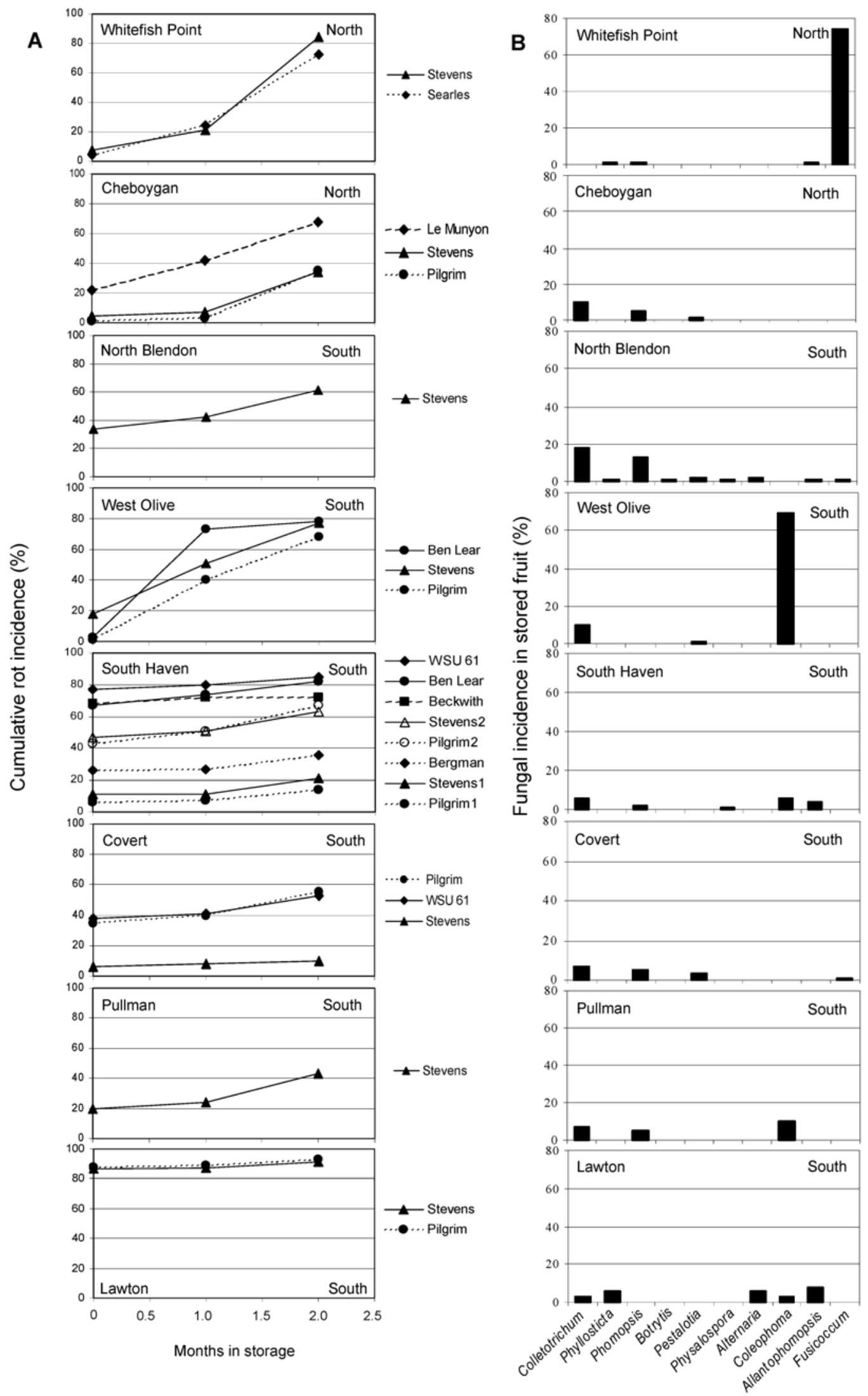

Fig. 1. A, Cumulative rot incidence in samples of 100 berries from Michigan cranberry beds on eight farms in 2000 at harvest (0 months) and after 1 and 2 months in storage at $5^{\circ} \mathrm{C}$. The number of beds per cultivar on each farm ranged from 1 to 4 . The South Haven farm consisted of two sites. One site contained cvs. Pilgrim and Stevens only (labeled "Pilgrim2" and "Stevens2" in the graph), and the other site contained cvs. Pilgrim and Stevens (labeled "Pilgrim1 and Stevens 1") and the four remaining cultivars. B, Incidence of specific fungi in cranberries that were nonsymptomatic at harvest and stored for 2 months at $5^{\circ} \mathrm{C}$ in 2000 in Michigan. Fungi were isolated only from rotted fruit. Incidence of individual fungi at harvest is described in Olatinwo et al. (7). Bars represent the mean incidence over all cultivars and beds on each farm. 
2001 in the south, only WSU 61 yielded more $P$. vaccinii than Pilgrim, Bergman, Ben Lear, and Beckwith $(P<0.05)$; however, rot incidence generally was low (Fig. 2B).

\section{DISCUSSION}

Storage rot was found to be a significant problem in cranberry samples from various locations in Michigan, particularly in 2000. The lower rot incidence in 2001 is attributed to a prolonged dry period during fruit development that year. Storage rot also was more common in the northern than in the southern part of the state in both years. Differences in climatic conditions as well as grower practices likely are responsible for the differences observed. The amount of field rot at harvest did not appear to be related to rot development in storage in this study, which agrees with findings in the northeastern United States reported by Oudemans et al. (8). This suggests that the amount of field rot is not an indicator of the potential for storage rot. On the other hand, serious losses may occur during storage of cranberries that show little rot at the time of harvest, as was the case with cranberries from Whitefish Point, UP.
Multiple fungi were associated with the development of storage rot in this study, confirming previous reports that cranberry fruit rot is a dynamic disease complex in which different fungal species predominate at different locations, and that frequencies can vary greatly over time $(8,16)$. However, the diversity of fungi causing storage rot in cranberries was less than the diversity of field rot pathogens in the same fields in a previous study (7). Some of the fungi isolated from cranberries that developed storage rot in this study are known storage rot pathogens (e.g., F. putrefaciens, Coleophoma empetri, and P. vaccinii; 2,8),
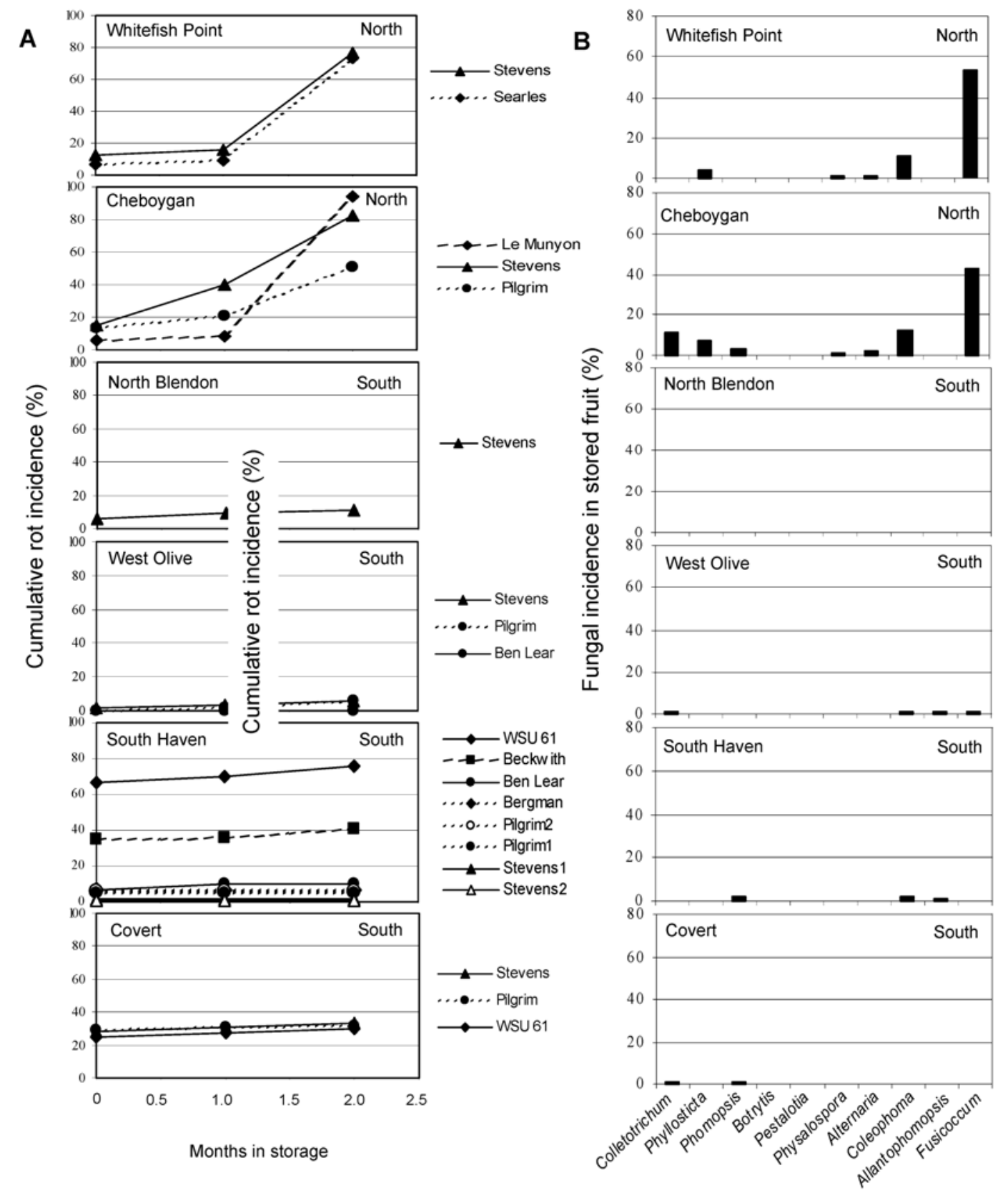

Fig. 2. A, Cumulative rot incidence in samples of 100 berries from Michigan cranberry beds on six farms in 2001 at harvest ( 0 months) and after 1 and 2 months in storage at $5^{\circ} \mathrm{C}$. The number of beds per cultivar on each farm ranged from 1 to 4 . The South Haven farm consisted of two sites. One site contained cvs. Pilgrim and Stevens only (labeled "Pilgrim2" and "Stevens2" in the graph), and the other site contained cvs. Pilgrim and Stevens (labeled "Pilgrim1 and Stevens1") and the four remaining cultivars. B, Incidence of specific fungi in cranberries that were nonsymptomatic at harvest and stored for 2 months at $5^{\circ} \mathrm{C}$ in 2001 in Michigan. Fungi were isolated only from rotted fruit. Incidence of individual fungi at harvest is described in Olatinwo et al. (7). Bars represent the mean incidence over all cultivars and beds on each farm. 
whereas others have not been reported previously as such (e.g., Colletotrichum acutatum). In Michigan, the latter fungus also commonly causes field rot in cranberries (7) and pre- and postharvest fruit rot of blueberries (10). Most storage rot pathogens in this study also were found in rotted fruit from the same fields at harvest, albeit mostly at low to moderate frequencies (7). However, Phyllosticta elongata was detected only in sound fruit at harvest (7), suggesting that it caused a latent infection that later progressed to a storage rot (2).

The incidence of specific fungi in stored cranberries with rot symptoms varied by region and year. F. putrefaciens, for example, largely was restricted to the northern part of Michigan. This fungus also is the most common storage rot pathogen of cranberries in Wisconsin $(4,12,14)$, whereas Shear (13) considered F. putrefaciens the most important fruit-rotting fungus of cranberries in North America. The high incidence of this fungus in stored fruit from the UP of Michigan may be linked to the cooler climate. This fungus also is a limiting factor to blueberry production in this area (2). Most cranberry fruit rot fungi grow very slowly below $10^{\circ} \mathrm{C}$, with the notable exception of $F$. putrefaciens, suggesting that it is adapted to cold climates and would have an advantage over other fungi under refrigerated conditions (2). Although $F$. putrefaciens is primarily a storage rot pathogen, infections may occur in the field prior to harvest and remain latent $(2,5)$. This fungus also was isolated at low to moderate frequencies from fruit showing field rot at the time of harvest (7).

Although this study did not reveal significant differences among cultivars in overall levels of storage rot, the fruit of some cultivars yielded significantly more C. acutatum or Phomopsis vaccinii than others. These results differ from those of Stiles and Oudemans (16), who concluded that rot resistance among 11 different cranberry cultivars was nonspecific based on the similarity of their fungal profiles. However, differences among cultivars in the incidence of fruit-rotting fungi had been found in Massachusetts (8). Cultivars reportedly also vary in susceptibility to infection by $F$. putrefaciens from one growing region to another. At Whitefish Point, UP, cvs. Searles and Stevens appeared equally susceptible to end rot in both years of this study. However, Stevens was reported to be resistant to end rot in Wisconsin and susceptible in the Pacific Northwest (2). These differences suggest the possibility of physiologic specialization in the pathogen.

The method of harvesting cranberry fruit also may play an important role in the development of storage rot $(6,11)$. A study in Wisconsin showed that the incidence of fruit rot after 12 weeks in storage ranged from 6 to $10 \%$ for cranberries that were "wet harvested" by machine, but was only
1 to $2 \%$ for fruit harvested by dry hand raking (6). When cranberry beds are flooded, large numbers of spores can be found in the floodwater, and these spores can cause infections at wound sites inflicted on the fruit during harvest (11). In

the current study, all fruit were hand harvested just prior to commercial harvest. Therefore, it is possible that the true incidence of storage rot in commercial cranberry fruit was underestimated. This also may explain why Allantophomopsis spp.

Table 1. Mixed model analysis (type 3 tests) of fixed effects on the rate of increase of storage rot in cranberry fruit harvested from beds in northern and southern Michigan in 2000 and 2001 and stored for 2 months at $5^{\circ} \mathrm{C}^{\mathrm{a}}$

\begin{tabular}{lccrr}
\hline Effect & Numerator df & Denominator df & $\boldsymbol{F}$ value & \multicolumn{1}{c}{$\boldsymbol{P}>\boldsymbol{F}$} \\
\hline Region & 1 & 7 & 17.87 & 0.0039 \\
Year & 1 & 26 & $2,251.54$ & $<0.0001$ \\
Region $\times$ year & 1 & 26 & $12,256.90$ & $<0.0001$ \\
Cultivar (region) & 8 & 28 & 0.82 & 0.5884 \\
\hline
\end{tabular}

${ }^{a}$ Rate of increase measured by the slope of the linear regression of rot incidence (percent) versus storage time (in months).

Table 2. Comparison of the frequency of occurrence of selected fungi in apparently healthy cranberry fruit harvested from beds in northern and southern Michigan in 2000 and 2001 and stored for 2 months at $5^{\circ} \mathrm{C}$

\begin{tabular}{|c|c|c|c|c|}
\hline \multirow[b]{2}{*}{ Pathogen, year } & \multirow[b]{2}{*}{ Region $^{\mathbf{a}}$} & \multicolumn{2}{|c|}{ Number of beds with fungus } & \multirow[b]{2}{*}{$P$ value } \\
\hline & & Present & Absent & \\
\hline \multicolumn{5}{|c|}{ Coleophoma empetri } \\
\hline \multirow[t]{2}{*}{2000} & North & 3 & 10 & 0.15 \\
\hline & South & 10 & 10 & \\
\hline \multirow{2}{*}{2001} & North & 11 & 2 & 0.0018 \\
\hline & South & 3 & 12 & $\ldots$ \\
\hline \multicolumn{5}{|c|}{ Colletotrichum acutatum } \\
\hline \multirow{2}{*}{2000} & North & 6 & 7 & 0.14 \\
\hline & South & 15 & 5 & \\
\hline \multirow[t]{2}{*}{2001} & North & 5 & 8 & 0.41 \\
\hline & South & 3 & 12 & $\ldots$ \\
\hline \multicolumn{5}{|c|}{ Fusicoccum putrefaciens } \\
\hline \multirow{2}{*}{2000} & North & 10 & 3 & $<0.0001$ \\
\hline & South & 3 & 17 & \\
\hline \multirow[t]{2}{*}{2001} & North & 13 & 0 & $<0.0001$ \\
\hline & South & 1 & 14 & $\ldots$ \\
\hline \multicolumn{5}{|c|}{ Phomopsis vaccinii } \\
\hline \multirow[t]{2}{*}{2000} & North & 8 & 5 & 0.48 \\
\hline & South & 9 & 11 & \\
\hline \multirow[t]{2}{*}{2001} & North & 7 & 6 & 0.11 \\
\hline & South & 3 & 12 & $\ldots$ \\
\hline \multicolumn{5}{|c|}{ Phyllosticta elongata } \\
\hline \multirow[t]{2}{*}{2000} & North & 2 & 11 & 0.68 \\
\hline & South & 5 & 15 & \\
\hline \multirow[t]{2}{*}{2001} & North & 10 & 3 & 0.0016 \\
\hline & South & 2 & 13 & $\ldots$ \\
\hline
\end{tabular}

${ }^{a}$ The northern region comprised Whitefish Point and Cheboygan, whereas the southern region comprised all other farm locations in Michigan.

b $P$-value for Fisher's exact test indicates the probability that the frequencies are equal.

Table 3. Frequency of linear correlations between the incidence of fruit rot and the incidence of specific fungi in Michigan cranberry samples stored at $5^{\circ} \mathrm{C}$ for 2 months in 2000 and 2001

\begin{tabular}{|c|c|c|c|c|}
\hline \multirow[b]{3}{*}{ Fungus $^{\text {b }}$} & \multicolumn{4}{|c|}{ Number of beds with significant linear correlation ${ }^{a}$} \\
\hline & \multicolumn{2}{|c|}{2000} & \multicolumn{2}{|c|}{2001} \\
\hline & North & South & North & South \\
\hline Fusicoccum putrefaciens & 8 & 0 & 11 & 0 \\
\hline Coleophoma empetri & 0 & 6 & 5 & 1 \\
\hline Colletotrichum acutatum & 3 & 6 & 2 & 1 \\
\hline Phyllosticta elongata & 0 & 0 & 4 & 0 \\
\hline Phomopsis vaccinii & 2 & 4 & 0 & 1 \\
\hline Total number of beds & 13 & 20 & 13 & 15 \\
\hline
\end{tabular}

a A correlation was considered statistically and biologically significant if $P \leq 0.10, R^{2} \geq 0.95$, and the slope was between 1 and 10. The northern region comprised Whitefish Point and Cheboygan, whereas the southern region comprised all other farm locations in Michigan.

${ }^{\mathrm{b}}$ Only fungi that were significantly correlated with storage rot incidence according to the criteria mentioned above are listed. 
were isolated only rarely from berries that rotted in storage.

McManus (6) also found that the range of fungi isolated from rotten fruit was greater for the wet-harvest than the dryharvest method. For example, F. putrefaciens and Physalospora vaccinii were common in rotten fruit regardless of harvest method. However, Coleophoma empetri, Allantophomopsis spp., and yeasts were more common in wet-harvested fruit than in dry-raked fruit (6). In this study, however, C. empetri was fairly common in the hand-harvested samples, suggesting that flooding is not required for infection by this fungus.

Although fungicide applications during bloom and early fruit development have shown good control of field rot (8), the utility of fungicides in reducing storage rot is unclear. Some studies have shown slight reductions in storage rot incidence when fungicides are applied two or more times from bloom onward $(4,5)$. However, fruit damaged during harvest deteriorated quickly in storage regardless of fungicides applied during the growing season (6). In the current study, some cranberry beds received one or two protectant fungicide applications during bloom, while other beds were not sprayed at all (7). The incidence of storage rot did not appear to be related to fungicide use.
This study indicates that storage rot can be a problem in Michigan in some years and locations, particularly in the northern growing region. This awareness may help growers decide whether to store or process fruit and aid in management decisions regarding harvest method and use of fungicides for fruit rot control.

\section{ACKNOWLEDGMENTS}

We thank the Michigan cranberry growers who kindly allowed us to sample fruit from their farms, and S. Berkheimer and S. Esman for assistance in collecting fruit.

\section{LITERATURE CITED}

1. Bain, H. F. 1926. Cranberry disease investigations on the Pacific Coast. U.S. Dep. Agric. Dep. Bull. 1434.

2. Caruso, F. L., and Ramsdell, D. C., eds. 1995. Compendium of Blueberry and Cranberry Diseases. The American Phytopathological Society, St. Paul, MN.

3. Corbett, L. C. 1903. Cranberry culture. U.S. Dep. Agric. Farmer's Bull. No. 176.

4. Jeffers, S. N. 1991. Effects of fungicides applied during bloom on yield, yield components, and storage rots of cranberry. Plant Dis. 75:244-250.

5. Jeffers, S. N. 1991. Seasonal incidence of fungi in symptomless cranberry leaves and fruit treated with fungicides during bloom. Phytopathology 81:636-644.

6. McManus, P. S. 2001. Cranberry fruit rot diseases in Wisconsin. Univ. Wis. Ext. Bull. A3745. Madison, WI.

7. Olatinwo, R. O., Hanson, E. J., and Schilder, A. M. C. 2003. A first assessment of the cran- berry fruit rot complex in Michigan. Plant Dis. 87:550-556.

8. Oudemans, P. V., Caruso, F. L., and Stretch, A. W. 1998. Cranberry fruit rot in the northeast: A complex disease. Plant Dis. 82:1176-1184.

9. Roger, T. R., and Vorsa, N. 1997. Cranberry: botany and horticulture. Hortic. Rev. 21:215249.

10. Schilder, A. M. C., and Gillett, J. M. 1999. Prevalence of fruit rotting fungi in blueberry fields in Michigan. (Abstr.) Phytopathology 89:S69.

11. Schwarz, M. R., and Boone, D. M. 1985. Effect of wounding on incidence of black rot of cranberry in Wisconsin. Plant Dis. 69:225227.

12. Shear, C. L. 1907. Cranberry diseases. U.S Dep. Agric. Bur. Plant Ind. Bull. 110. Washington, DC.

13. Shear, C. L., and Bain, H. F. 1929. Life history and pathological aspects of Godronia cassandrae Peck. (Fusicoccum putrefaciens Shear) on cranberry. Phytopathology 19:1017-1024.

14. Shear, C. L., Stevens, N. E., and Bain, H. F. 1931. Fungous diseases of the cultivated cranberry. U.S. Dep. Agric. Tech. Bull. 258. Washington, DC.

15. Stiles, C. M., and Oudemans, P. V. 1997 Cranberry fruit rot pathogens isolated from various cranberry plant tissues over two growing seasons. (Abstr.) Phytopathology 87:S94.

16. Stiles, C. M., and Oudemans, P. V. 1999. Distribution of cranberry fruit-rotting fungi in New Jersey and evidence for nonspecific host resistance. Phytopathology 89:218-225.

17. Stretch, A. W., and Ceponis, M. J. 1983. Influence of water immersion time and storage period on black rot development in cold-stored, waterharvested cranberries. Plant Dis. 67:21-23. 